\title{
Aplikasi Administrasi Gudang Sparepart PT Lasallefood Indonesia Berbasis Dekstop
}

\author{
William Renault ${ }^{1 *}$, Nilma, M.Kom. ${ }^{1}$, dan Thomas Afrizal, M.Kom. ${ }^{3}$ \\ ${ }^{123}$ Universitas Indraprasta PGRI \\ Jl. Raya Tengah No.80, RT.6/RW.1, Kel. Gedong, Kec. Pasar Rebo \\ Kota Jakarta Timur, Daerah Istimewa Jakarta 13760 \\ willi.ww18@gmail.com, nilma23juli@gmail.com, thomztaurus.it@gmail.com
}

\begin{abstract}
Abstrak - PT Lasallefood Indonesia merupakan suatu perusahaan yang bergerak pada bidang manufaktur dan pemasaran serta contract manufacturing makanan dan minuman, dalam proses produksi selalu ada kendala dimana sering terjadi kesalahan dalam setiap pencatatan disebabkan penginputan data memerlukan waktu yang lama, serta penyimpanan data belum menggunakan file database. Dalam praktiknya admin selalu melakukan pendataan terhadap penggunaan sparepart dan alat pendukung yang dibeli tanpa ada proses Purches Order (PO) dengan memasukan data tersebut kedalam Microsoft Excel. System manual seperti ini membutuhkan waktu dan tenaga yang cukup besar, penelitian kali ini peneliti menggunakan metode Grounded Research dimana penelitian ini mendasarkan kepada fakta dan menggunakan analisa perbandingan bertujuan untuk mengadakan generelasi empiris, menetapkan konsep- konsep, membuktikan teori dan mengembangkan teori dimana pengumpulan data dan analisa data berjalan pada waktu yang bersamaan. Sistem ini dirancang untuk mempemudah dan proses presensi dan penggajian pada Pt lasallefood.
\end{abstract}

Kata kunci: Aplikasi, Administrasi, Berbasis Dekstop

Abstract-PT Lasallefood Indonesia is a company engaged in manufacturing and marketing as well as contract manufacturing of food and beverages, in the production process there are always obstacles where errors often occur in every recording due to data input takes a long time, and data storage has not used a database file. In practice, the admin always collects data on the use of spare parts and supporting tools purchased without a Purches Order (PO) process by entering the data into Microsoft Excel. Manual systems like this require considerable time and energy, this time the researcher uses the Grounded Research method where this research is based on facts and uses comparative analysis aimed at conducting empirical generations, establishing concepts, proving theories and developing theories in which data collection and data analysis running at the same time. This system is designed to simplify and process attendance and payroll at Pt Lasallefood.

Keywords: Application, Administration, Desktop Based

\section{Pendahuluan}

aplikasi adalah satu unit perangkat lunak yang dibuat untuk melayani kebutuhan akan beberapa aktiitas seperti sistem penjadwalan game, pelayanan masyarakat, periklanan atau semua proses yang dilakukan oleh manusia[1]. Administrasi memiliki dua pengertian, yaitu administrasi dalam arti sempit dan administrasi dalam arti luas. Administrasi dalam arti sempit adalah kegiatan penyusunan dan pencatatan data dan informasi secara sistematis dengan tujuan untuk menyediakan keterangan atau sebuah informasi serta memudahkan memperolehnya kembali secara keseluruhan dan dalam satu hubungan satu sama lain[2]. Gudang adalah suatu tempat yang digunakan untuk menyimpan barang, baik berupa raw material, atau finished good, dari kata gudang, didapatkan istilah pergudangan yang memiliki arti suatu kegiatan yang berkaitan dengan Gudang [3] .Tujuan dari penyimpanan dan fungsi gudang yaitu untuk memaksimalkan utilitas sumber - sumber yang ada ketika memenuhi keinginan konsumen dan juga untuk memaksimalkan pelayanan terhadap konsumen dengan kendala - kendala sumber yang ada

\section{Tinjauan Pustaka}

2.1. Aplikasi

aplikasi adalah program yang dibuat untuk melaksanakan tugas tertentu yang dibutuhkan oleh pengguna komputer (user).[1] 


\section{Administrasi}

Administrasi adalah suatu kegiatan proses, terutama mengenai cara-cara, sarana untuk mencapai tujuan yang telah dditentukan[4].

23. UML

Uml adalah salah satu standar bahasa yang banyak digunakan di dunia industri untuk mendefinisikan requirement, membuat analisis $\&$ desain, serta menggambarkan arsitektur dalam pemrograman berorentasi objek.[5]

24. $\mathrm{MySq} 1$

MySQL adalah sebuah program server basis data yang mampu menerima dan mengirimkan data dengan cepat menggunakan perintah-perintah SQL. MySQL dapat menampung data dalam jumlah yang sangat besar, dapat diakses oleh banyak pengguna (multi-user) dan dapat melakukan suatu proses secara sinkron atau bersamaan (multi-threaded)[3].

25. Use Case

Mengidentifikasi fitur kunci dari sistem. Tanpa fitur ini, sistem tidak akan memenuhi permintaan user/aktor. Setiap use case mengekspresikan goal dari sistem yang harus dicapai.[6]

26. Class Diagram

Class diagram adalah model statis yang menggambarkan struktur dan deskripsi class serta hubungannya antara class. Class diagram mirip ER Diagram pada perancangan database, bedanya pada ER-diagram tidak terdapat operasi/methode tapi hanya atribut.[6]

2.7. Java

Java adalah Bahasa pemrograman yang dapat dijalankan diberbagai computer. Java berdiri disebuah mesin yang diberinama Java Virtual Machine (JVM).[7]

28. Netbenans

Netbeans adalah sebuah IDE (integrated development environment) open source yang sering kali diasosiasikan dengan Java. Akan tetapi bila diperhatikan IDE yang satu ini tidak hanya dapat digunakan sabagai IDE untuk membuat proyek-proyek Java saja, melainkan juga proyek seperti web service.[7]

\section{Metode Penelitian}

Metode penelitian yang peneliti gunakan untuk mendapatkan informasi serta data-data yang diperlukan adalah menggunakan metode deskriptif dengan tujuan untuk mendapatkan data secara detail, mendalam, dan juga aktual. Untuk mendapatkan data dan informasi dalam mendukung penyempurnaan hasil dari penelitian ini, maka peneliti melakukan metode pengumpulan data antara lain:

1. Metode observasi (Pengamatan langsung)

Peneliti melakukan pengamatan langsung kelapangan dengan mengamati pelaksanaan sistem yang sedang berjalan.

2. Metode interview (Wawancara)

Peneliti melakukan tanya jawab kepada kepala sekolah, tata usaha dan guru yang berkaitan dengan masalah yang di pecahkan sehingga memperoleh data-data yang benar-benar akurat.

3. Metode Studi Kepustakaan (Literature)

Metode pengummpulan data dengan mempelajari literature bahan pustaka baik berupa dokumen tertulis maupun berupa gambar dan mengambil teori-teori yang berhubungan dengan judul penelitian ini. 


\section{Hasil dan Pembahasan}

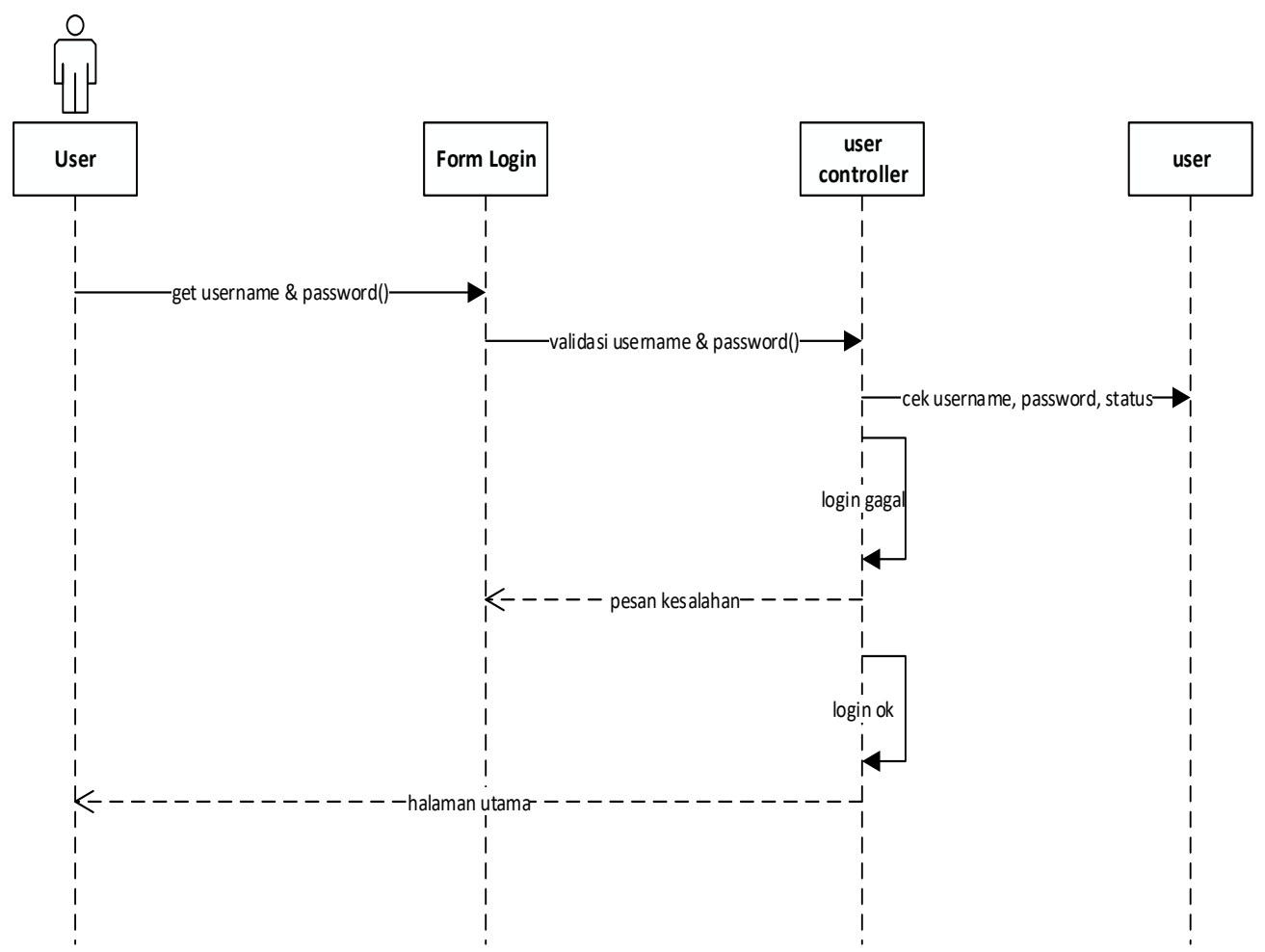

Gambar 1. Sequence Diagram login 
P-ISSN 2620-8342

E-ISSN 2621-3052

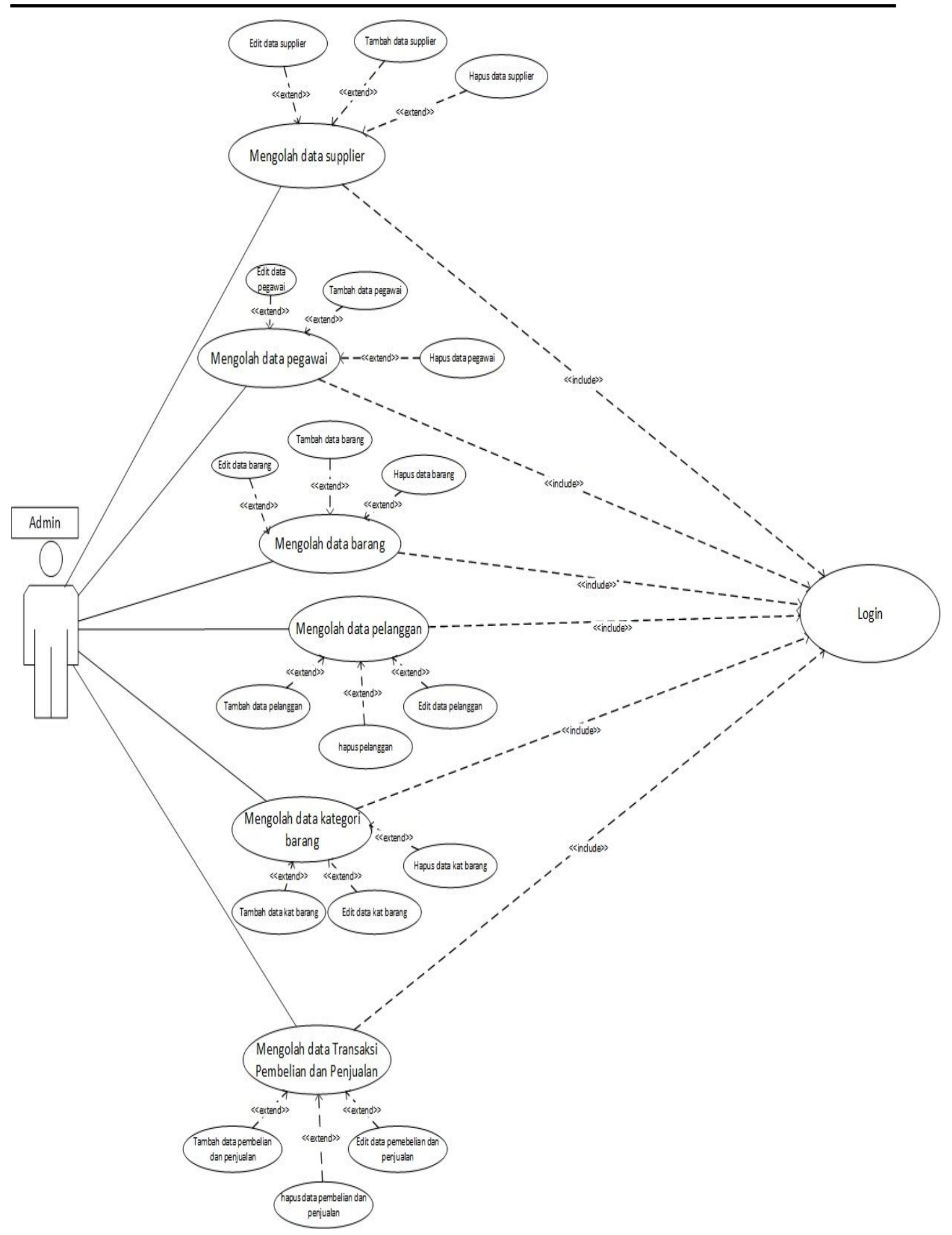

Gambar 2. Use Case Diagram 


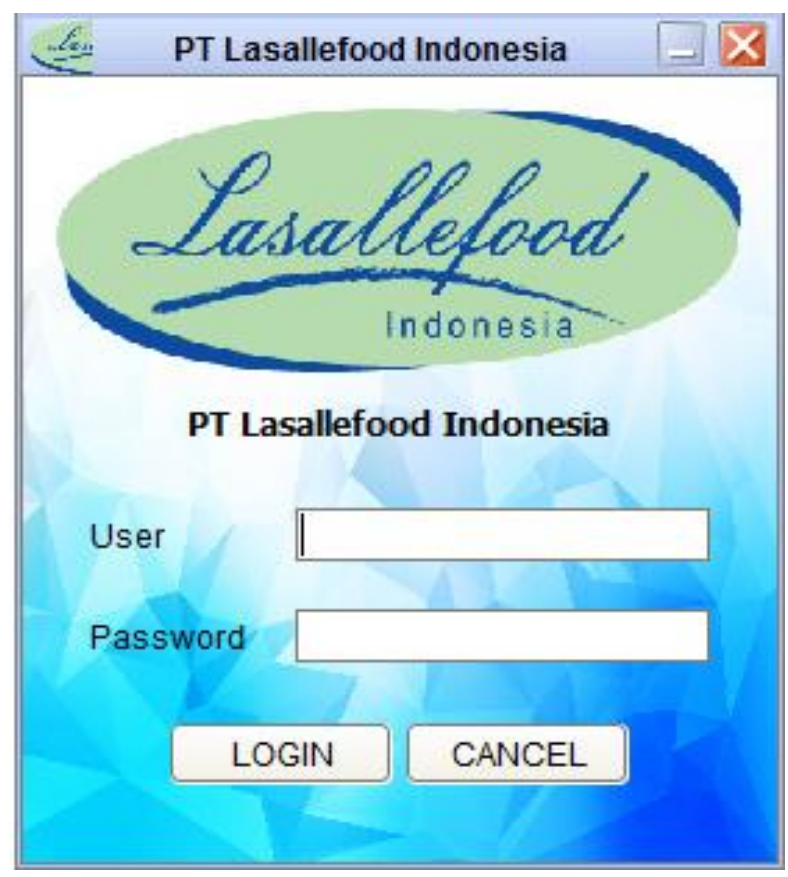

Gambar 3. Halaman Login

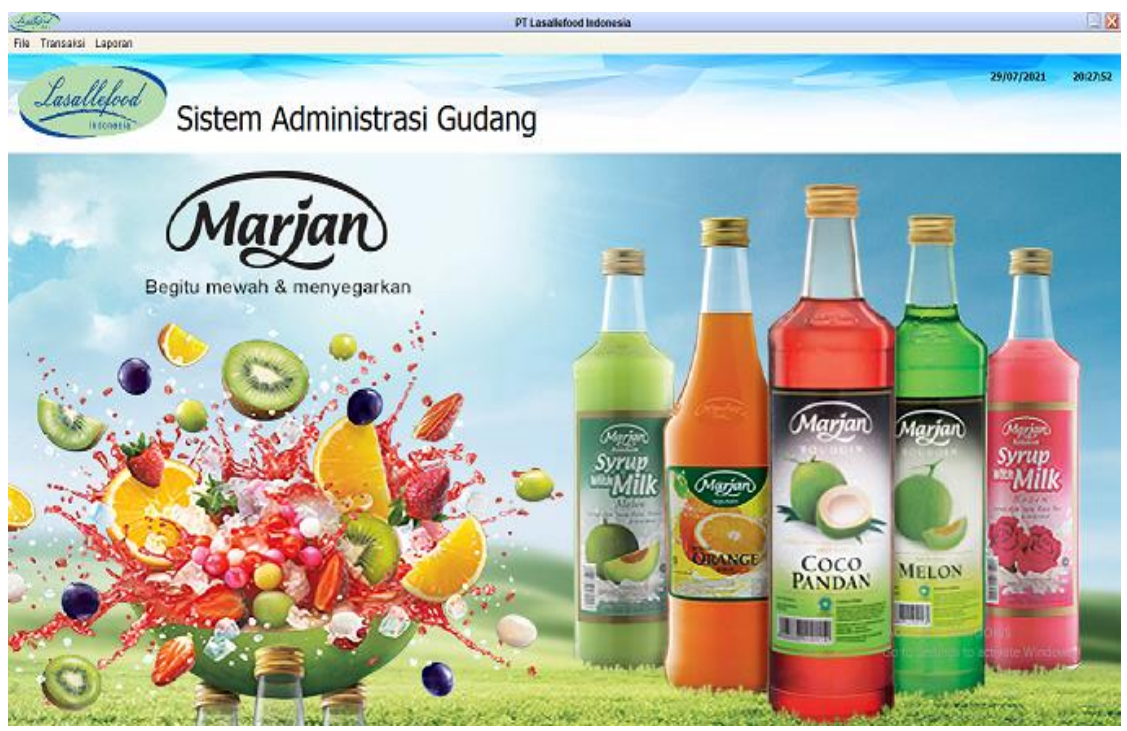

Gambar 4. Halaman Menu Utama 


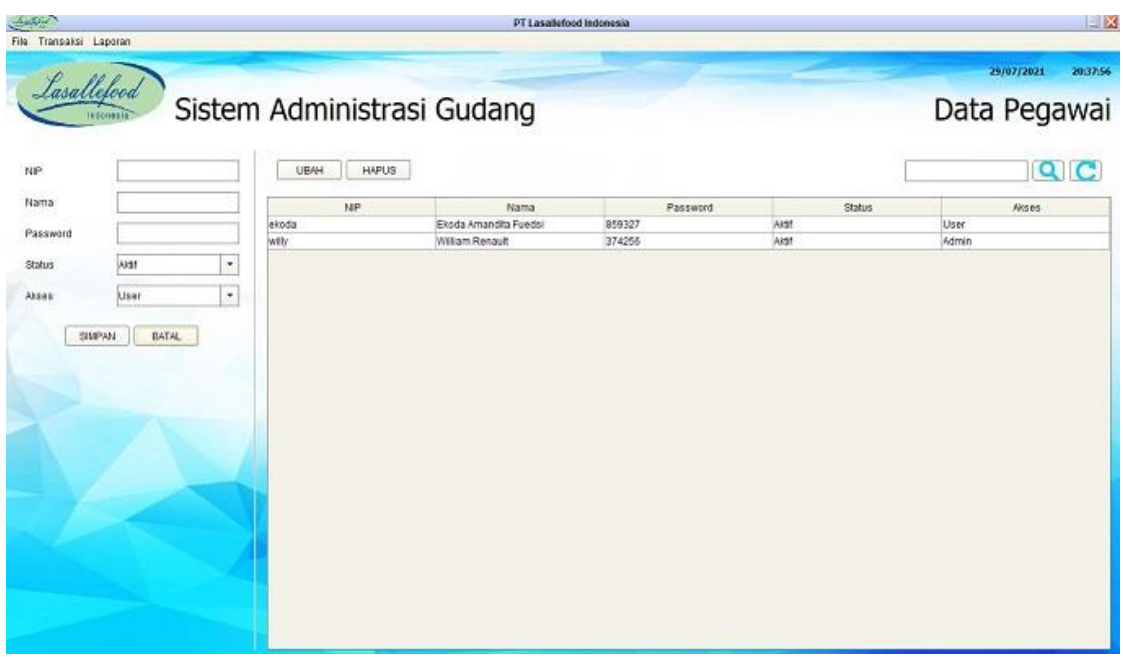

Gambar 5. Halaman Data Pegawai

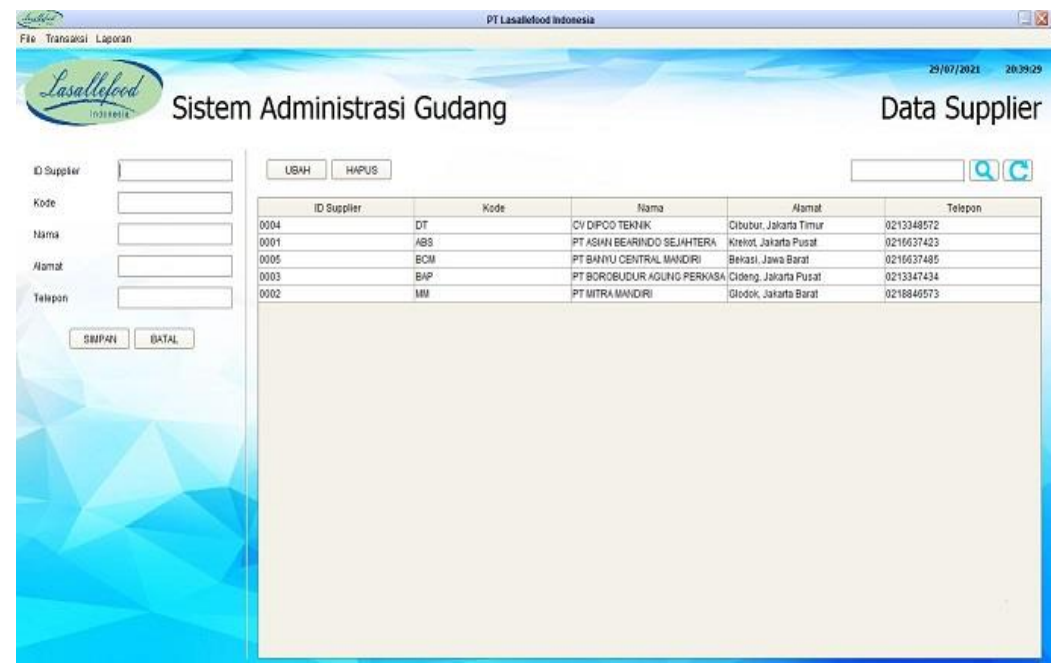

Gambar 6. Halaman Data Supplier

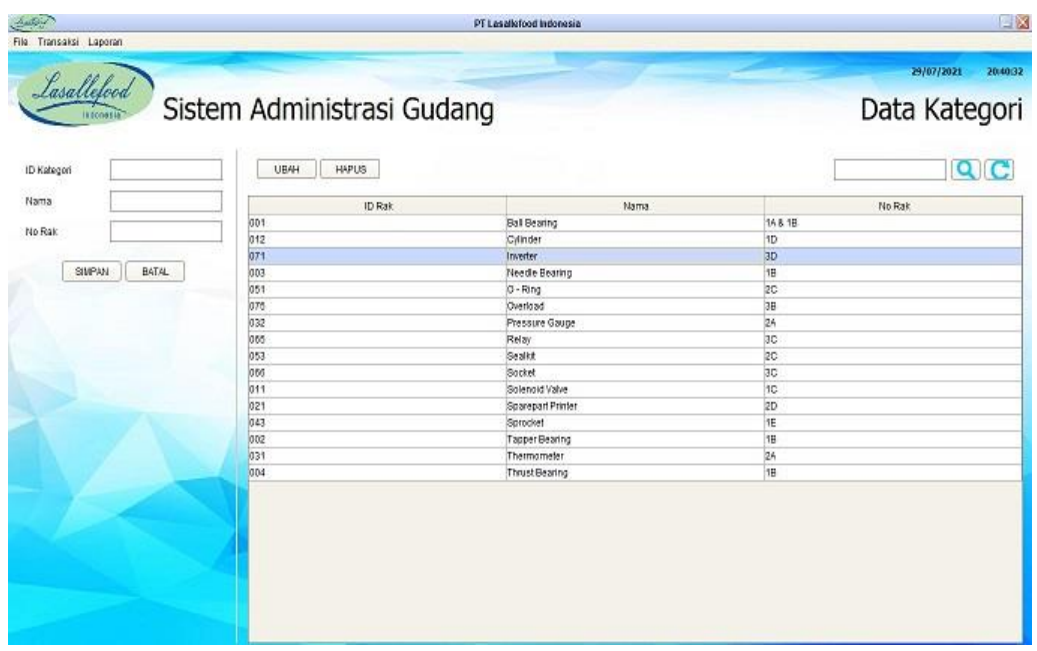

Gambar 7. Halaman Data Kategori 
P-ISSN 2620-8342

E-ISSN 2621-3052

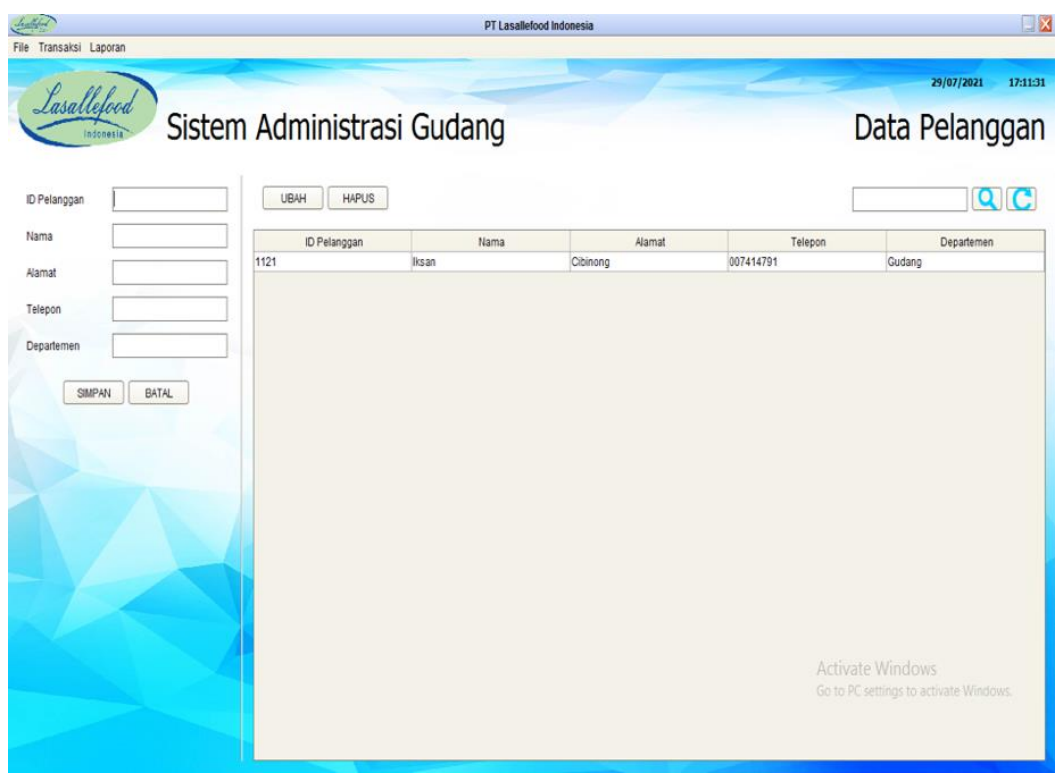

Gambar 8. Halaman Data Pelanggan

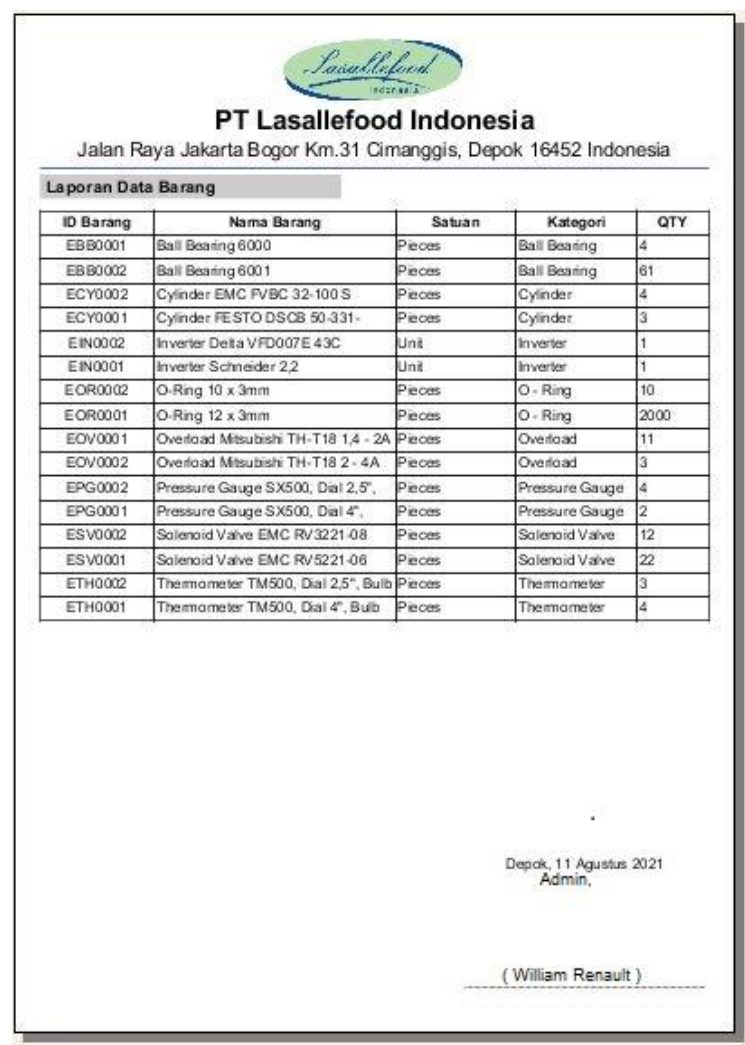

Gambar 9. Halaman Laporan Data Barang 


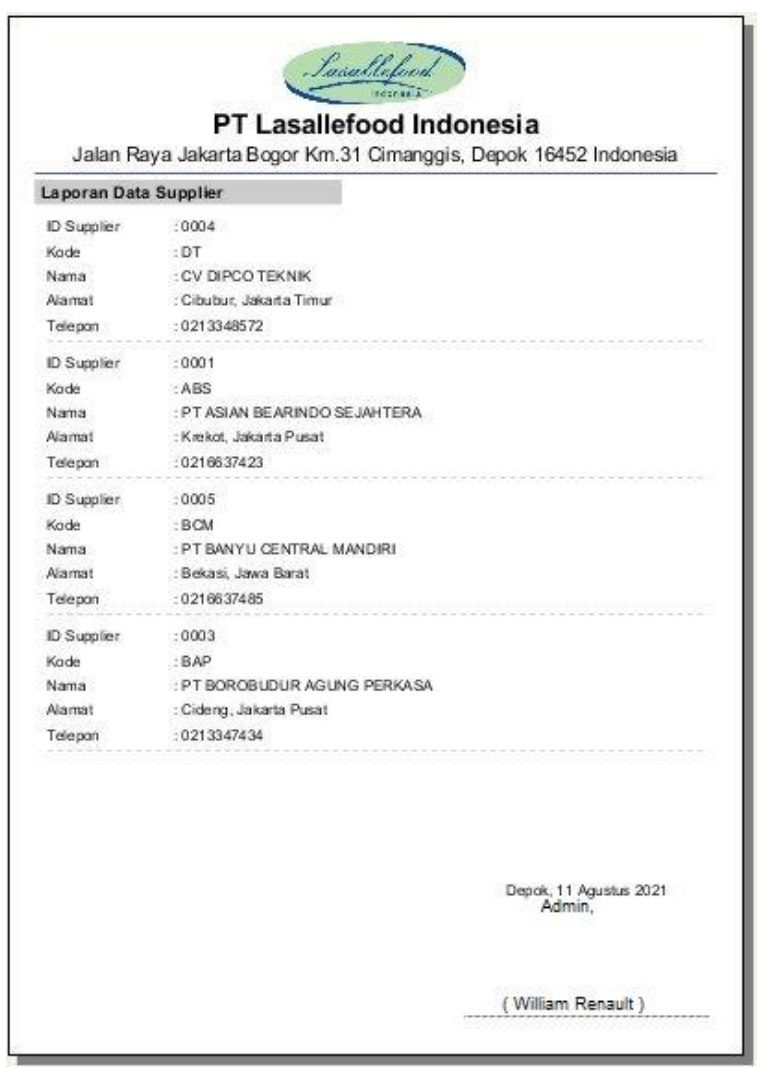

Gambar 10. Halaman Laporan Data Supplier

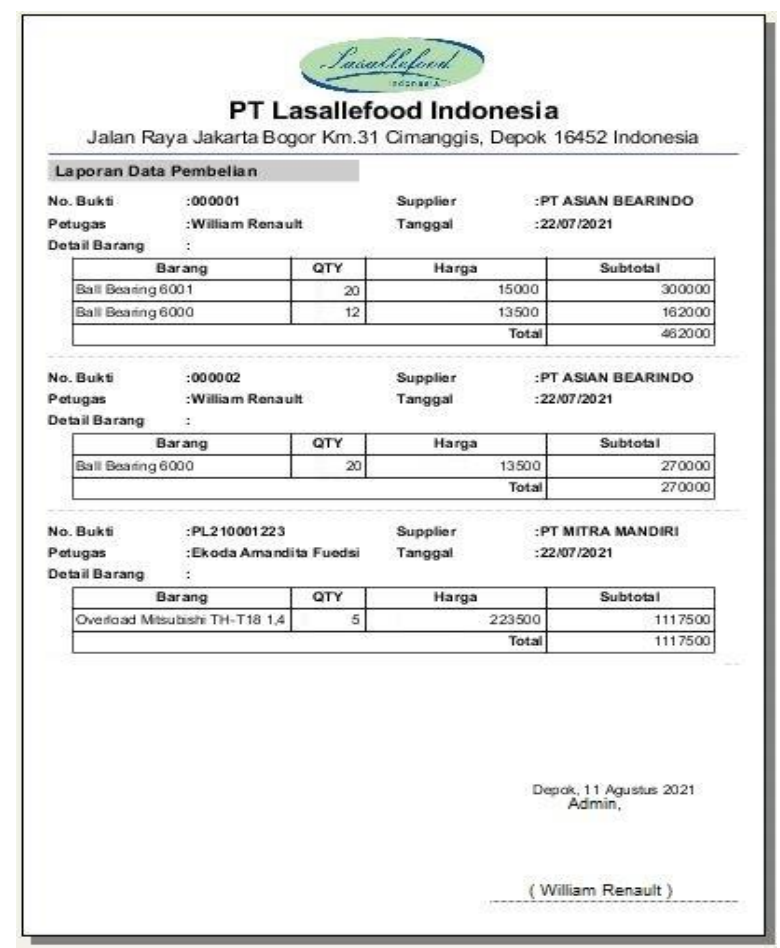

Gambar 11. Halaman Laporan Data Pembelian 


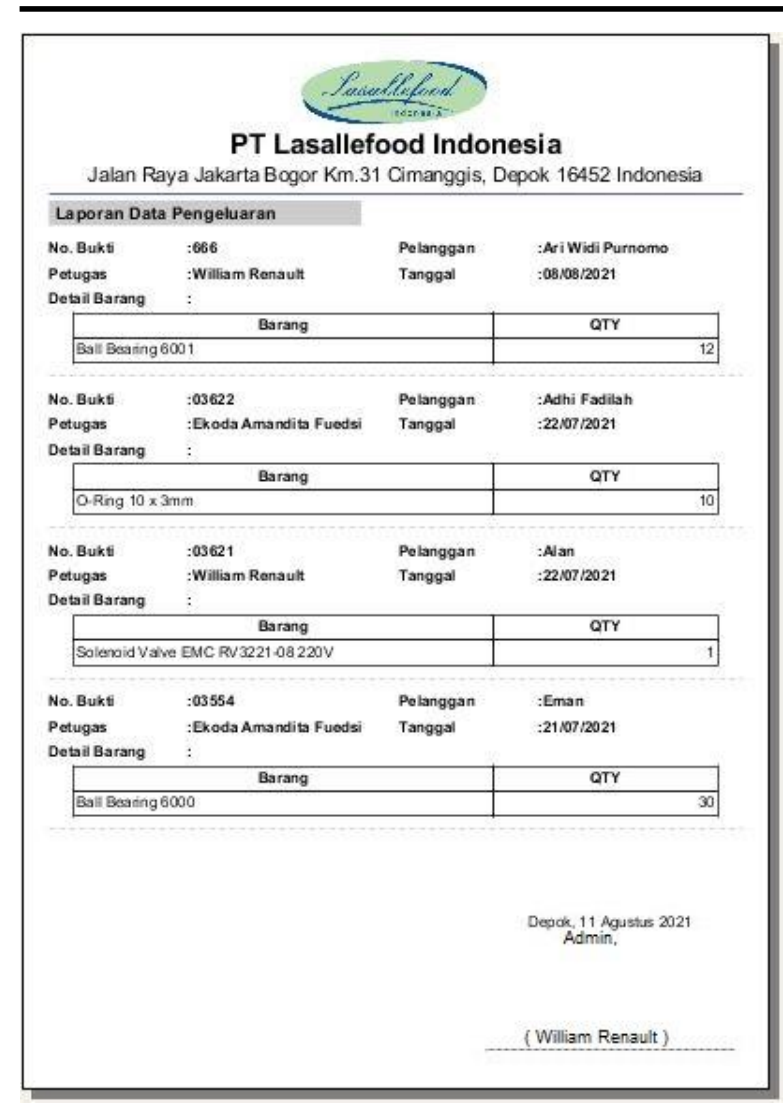

Gambar 12. Halaman Laporan Data Pengeluaran

\section{Kesimpulan}

Penggunaan sistem komputerisasi pada bagian gudang sparepart PT Lasallefood Indonesia diharapkan akan mempermudah kegiatan pengelolaan data oleh pimpinan, bagian Accounting dan bagian Produksi. Adapun kesimpulan dari penelitian ini adalah :

1. Merancang suatu informasi pembelian sparepart tanpa Purchase Order agar terdata di gudang sparepart PT Lasallefood Indonesia.

2. Merancang suatu informasi penggunaan sparepart di bagian produksi.

3. Membangun aplikasi yang telah disesuaikan dengan proses yang berjalan pada gudang sparepart PT Lasallefood Indonesia untuk memudahkan dalam pengolahan data persediaan sparepart.

4. Membuat rancangan laporan berdasarkan kegiatan administrasi yang terjadi pada gudang sparepart PT Lasallefood Indonesia.

\section{Daftar Pustaka}

[1] Yakub, Pengantar Sistem Informasi. Yogyakarta: Graha Ilmu, 2012.

[2] Sutabri T, Analisa Sistem Informasi. Yogyakarta: Andi Ofset, 2012.

[3] H. 1 Zalukhu S, "Analisa Dan Perancangan Aplikasi Sistem Inventory (Studi Kasus: Pt. Cakra Medika Utama)," JSAI, vol. 2 Nomor 1, 2019.

[4] Y. W. Aswin, M. Mudjianto, and R. Ningsih, "Sistem Informasi Inventory Pada Hotel Maharani," J. Nas. Komputasi Dan Teknol. Inf. JNKTI, vol. 3, no. 3, Art. no. 3, Dec. 2020, doi: 10.32672/jnkti.v3i3.2488.

[5] E. Affandi and T. Syahputra, "Pemodelan Uml Manajeman Sistem Inventory," J. Teknol. Sist. Inf. Dan Sist. Komput. TGD, vol. 1, no. 2, Art. no. 2, Jul. 2018, doi: 10.53513/jsk.v1i2.27.

[6] T. A. Kurniawan, "Pemodelan Use Case (UML): Evaluasi Terhadap beberapa Kesalahan dalam Praktik," J. Teknol. Inf. Dan Ilmu Komput., vol. 5, no. 1, Art. no. 1, Mar. 2018, doi: 10.25126/jtik.201851610.

[7] Irawan, Pemrograman Database Dengan Java. Palembang: Maxicom, 2013. 